\begin{tabular}{|c|c|}
\hline 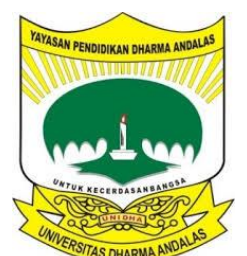 & $\begin{array}{c}\text { Jurnal Ekonomi dan Bisnis } \\
\text { Dharma Andalas }\end{array}$ \\
\hline
\end{tabular}

\title{
Pengaruh Kompetensi Sosial dan Kompetensi Profesional Terhadap Penilaian Kinerja Dosen Universitas Dharma Andalas Padang
}

\author{
Melda Novita ${ }^{1}$, Prima Yulianti ${ }^{2}$ \\ Fakultas Ekonomi dan BisnisUniversitas Dharma Andalas ${ }^{1,2}$ \\ email : primayulianti@unidha.ac.id ${ }^{2}$
}

\begin{abstract}
This study aims to determine the effect of pedagogical competence and personality competence on the performance appraisal of lecturers (Case Study in Management Department Students, Faculty of Economics and Business, Dharma Andalas University). This study uses the independent variable (X), namely Pedagogical Competence (X1), and Personality Competence $(X 2)$, and the dependent variable $(Y)$, Lecturer Performance Assessment $(Y)$. The population is all students majoring in management at FEB Dharma Andalas University. The sampling technique was random sampling with a total sample of 252 respondents. The data analysis method used is multiple linear regression analysis. The results obtained from this study indicate that both parsia and simultaneous pedagogical competence variables and personality competencies have a positive and significant effect on Lecturer Performance Assessment.
\end{abstract}

Keywords: pedagogical competence, personality competence, lecturer performance assessment

\section{ABSTRAK}

Penelitian ini bertujuan untuk mengetahui pengaruh kompetensi Sosial dan kompetensi Profesional terhadap penilaian kinerja Dosen Universitas Dharma Andalas. Penelitian ini menggunakan variabel bebas (X) yaitu Kompetensi Sosial (X1), dan Kompetensi Profesional (X2), serta variabel terikat (Y) yaitu Penilaian Kinerja Dosen (Y). Populasi adalah semua mahasiswa jurusan Akuntansi FEB Universitas Dharma Andalas. Teknik pengambilan sampel secara random sampling dengan jumlah sampel sebanyak 210 responden. Metode analisis data yang digunakan adalah analisis regresi linear berganda. Hasil yang didapat dari penelitian ini menunjukkan secara parsia maupun simultan variabel kompetensi Sosial dan kompetensi Profesional berpengaruh positif dan signifikan terhadap Penilaian Kinerja Dosen.

Kata Kunci: kompetensi sosial, kompetensi profesional, penilaian kinerja dosen

\section{PENDAHULUAN}

Pendidikan merupakan hal yang terpenting dalam membentuk masyarakat indonesia untuk mampu berprestasi dan bersaing secera sehat dan baik dalam kehidupan sehari-hari maupun dalam organisasi, maka di perlukan kolaborasi di berbagai pihak baik melalui perguruan tinggi atau sekolah dalam menyediakan sarana dan prasarana dan lingkungan yang baik melalui pelajar dan pengajarnya. Perguruan tinggi sangat berbeda dengan pendidikan wajib belajar dua belas tahun, perguruan tinggi lebih mengutamakan pendidikan dan pengajar orang dewasa. Dewasa maksudnya adalah terlibat lansung ,mandiri, mengarahkan diri sendiri untuk 
mencari jawaban dan untuk bertanya dalam pembelajaran orang dewasa, idenya sangat di hargai dan materi ajar sangat dibutuhkan karena merupakan suatu yang baru bagi dirinya.(Yulianti, 2019). Perguruan tinggi merupakan tempat penyelenggaran pendidikan yang bertujuan untuk menghasilkan sumber daya manusia yang berkualitas sehingga mampu menghadapi persaingan kerja yang semakin banyak. Sumber daya manusia yang berkualitas melakukan pekerjaan dengan baik dan menghasilkan kinerja yang tinggi dalam setiap pekerjaan, Kinerja merupakan hal yang sangat penting dilakukan oleh karyawan dalam perusahaan agar memenuhi target yang ingin dicapainya. (Yahya dan Hidayati, 2014).

Menurut Martoyo (dalam Yahya dan Hidayati, 2014 ) mengatakan bahwa penilaian kinerja karyawan merupakan penilaian yang sangat sistematik terhadap penampilan kinerja karyawan itu sendiri dan terhadap paraf potensi kinerja karyawan dalam upaya mengembangkan diri. Manfaat penilaian kinerja bagi perusahan adalah sebagai alat dalam pengambilan keputusan oleh pemimpin bermanfaat bagi karyawan untuk mengetahui kekurangan, potensi, tujuan, rencana dan pengembangan karir karyawan. Sedangkan manfaat penilaian kinerja bagi pergfuruan tinggi adalah sebagai alat dalam pengambilan keputusan dan Untuk merumuskan kebijakan sebagai upaya meningkatkan mutu pembelajaran dan pelayanan pendidikan sesuai dengan kebutuhan seluruh pemangku kepentingan. Sedangkan manfaat penilaian kinerja bagi dosen harus di lakukan untuk mengetahui prestasi yang dapat di lakukan oleh dosen untuk mewujudkan visi misi yang telah di terapkan oleh lembaga pendidikan. Dengan melakukan proses penilaian kinerja dosen maka prestasi yang di capai oleh setiap dosen dengan nilai yang baik dan cukup atau kurang bisa di ketahui oleh dosen sehingga dosen bisa melakukan kinerja yang lebih baik lagi. Penilaian kinerja dosen merupakan penilaian yang di lakukan untuk mengetahui kekurangan, tujuan, potensi dan pengembangan karir dosen.

Kinerja dosen sebagai tenaga pendidik di perguruan tinggi memiliki peran yang sangat penting. Dosen begitu dituntut untuk memperlihatkan kinerja yang baik. Dosen harus mampu menguasai materi, kemudian dosen mengajarkan kembali materi yang telah dikuasai kepada mahasiswa. Dengan begitu mahasiswa akan mudah mengerti terhadap materi yang diajarkan oleh dosen. Sehingga perguruan tinggi mampu menghasilkan mahasiswa yang berprestasi dan mampu dalam menghadapi persaingan. Dalam proses belajar, faktor keberhasilan mahasiwa bergantung bagaimana lembaga perguruan tinggi menghadirkan dosen yang berkualitas. Kompetensi merupakan gambaran hakekat kualitatif dan perilaku dosen yang tampak sangat berarti, kompetensi menjadi tuntutan mutlak pada tugas dan tanggung jawab yang menjadi keterampilan dan kemampuan yang dituntut oleh jabatan seseorang. Dengan menyimak makna kompetensi maka dapat dimaklumi jika kompetensi itu dipandang sebagai pilarnya atau teras kinerja dari suatu profesi. (Mattentuang, 2011).

Dosen yang di nyatakan sebagai pendidik yang profesional dan ilmuan dengan tugas utamanya adalah mengembangkan dan menyebarluaskan ilmu pengetahuannya melalui pendidikan dan pelatihan,pengabdian kepada masyarakat dan lingkungan. Sementara dosen di tuntut untuk dapat melihatkan kinerja yang baik salah satu peningkatan kinerja dosen bisa di lihat dari keberhasilan dosen dalam menerapkan standar kompetensi yang di atur dalam UU NO.14 Tahun 2005. Tentang 
kompetensi soaial dan kompetensi profesional kompetensi tersebut harus harus di penuhi oleh dosen selama dalam menyampaikan materi dalam perkulihan. (Fathorrahman, 2017).

Yang di maksud dengan kompetensi sosial merupakan kemampuan guru atau dosen sebagai bagian masyarakat yang memiliki kompetensi untuk berkomunikasi secara lisan maupun tulisan dan isyarat dengan menggunakan informasi dan teknilogi. Sedangkan menurut Surya (dalam Fathorrahman, 2017) mengemungkakan kompetensi sosial adalah kemampuan yang di perlukan oleh seseorang agar berhasil dalam berhubungan dengan orang lain dan kemampuan dosen dalam melakukan komunikasi dan interaksi secara efektif dan efisien dengan mahasiswa, sesama dosen, pimpinan, dan masyarakat. Kompetensi sosial juga merupakan kemampuan sangat di perlukan oleh seseorang agar berhasil dalam berhubungan dengan orang lain dan masyarakat.

Sedangkan

kompetensi profesional merupakan orang yang di pandang ahli dalam bidangnya dan penguasaan materi secara luas dan dalam sehingga dapat di nyatakn sebagia dosen yang profesional dan memungkinkan membimbing peserta didik memenuhi kewajiban nya dan memenuhi standar kompetensi yang di terapkan dalam standar nasional pendidikan. dengan memiliki kompetensi yang memadai maka seseorang dapat melakukan pekerjaan dan menghasilkan kinerja yang baik. (Fathorrahman, 2017)

Universitas Dharma Andalas merupakan salah satu kampus swasta yang berlokasi di jalan Sawahan No.103 A Simpang Haru, Padang. Universitas Dharma Andalas perlu memahami dan membimbing mahasiswa dengan memberikan dosen yang memiliki kompetensi, sehingga mahasiswa mampu dan siap dalam menghadapi persaingan kerja yang semakin ketat. Untuk menghasilkan mahasiswa tersebut, tentunya diperlukan kerja sama yang baik antara mahasiwa, dosen dan perguruan tinggi.

Dosen Universitas Dharma Andalas Padang merupakan salah satu aset memegang peranan penting dalam keberhasilan unidha padang serta mahasiswanya. Maka kinerja dosen di minta lebih efektif dan profesional lagi dalam membantu mahasiswa belajar, Universitas Dharma Andalas Padang dalam aktivitas kerja nya berusaha untuk selalu mengajarkan yang terbaik untuk mahasiswanya agar mahasiswanya kelak bisa menghadapi dunia kerja. Dimana manfaat dari kinerja tidak hanya di rasakan oleh individu tapi juga di rasakan oleh mahasiswa Universitas Dharma Andalas Padang.

Untuk meningkatkan kinerja dosen Universitas Dharma Andalas Padang atau setidak nya mempertahan kan kinerja yang sudah di raih saat ini agar tidak terjadi penurunan secara dratis, kiranya oleh itu di kaji ulang setiap faktor yang berperan di dalamnya, yaitu dosen Unidha padang harus profesional dalam mengajar mahasiswa dengan begitu bisa meningkatkan kinerja dosen Universitas Dharma Andalas Padang.

\section{Kompetensi Sosial}

Kompetensi sosial merupakan kemampuan dosen untuk berkomunikasi dan bergaul secara efektif dengan peserta didik, sama pendidik, tenaga pendidik, orang tua/ wali peserta didik, dan masyarakat sekitar. Kompetensi sosial merupakan kemampuan dosen untuk berkomunikasi dan bergaul secara efektif dengan peserta didik, sesama pendidik, tenaga pendidik, orang tua/wali peserta pendidik, dan masyarakat. ( Yahya dan Hidayati, 2014)Dosen yang efektif adalah dosen yang bisa membawa siswanya dengan berhasil mencapai tujuan pembalajaran. 
Mengajar di depan kelas merupakan perwujudan interaksi dalam kelas merupakan perwujudan interaksi dalam proses komunikasi.( Mattentuang, 2011). Menurut undang-undang guru dan dosen dijelaskan bahwa Kompetensi sosial adalah kemampuan dosen untuk berkomunikasi dan berinteraksi secara efektif dan efisien dengan peserta didik, sesama guru, orang tua/wali peserta didik dan masyarakat sekitar. (Mattentuang, 2011). Kompetensi sosial merupakan kemampuan yang diperlukan oleh seseorang agar berhasil dalam berhubungan dengan orang lain. Dalam kompetensi sosial ini termasuk keterampilan dalam interaksi sosial dan melaksanakan tanggung jawab sosial. Merujuk pada asian institute for teacher educatioan, dijelaskan bahwa kompetensi sosial dosen adalah salah satu daya atau kemampuan dosen untuk mempersiapkan peserta didik menjadi anggota masyarakat yang baik serta kemampuan untuk mendidik, membimbing masyarakat dalam menghadapi kehidupan di masa yang akan datang. (Mattentuang, 2011). Kompetensi sosial mengharuskan dosen memiliki kemampuan komunikasi sosial yang baik dengan peserta didik, sesama dosen , pimpinan , pegawai tata usaha, bahkan dengan anggota masyarakat. kemampuan sosial mencakup kemampuan untuk menyesuaikan diri kepada tuntutan kerja dan lingkungan sekitar pada waktu membawakan tugasnya sebagai dosen. Kompetensi ini berhubungan dengan kemampuan dosen sebagai anggota masyarakat dan sebagai makhluk sosial, meliputi kemampuan untuk berinteraksi dan berkomunikasi dengan teman sejawat untuk meningkatkan kemampuan profesional, kemampuan untuk mengenal dan memahami fungsi-fungsi setiap lembaga kemasyarakatan, dan kemampuan untuk enjalin kerja sama baik secara individual maupun secara kelompok. (Mattentuang,
2011). Dosen adalah makhluk sosial, yang dalam kehidupannya tidak bisa terlepas dari kehidupan sosial masyarakat dan lingkungannya, oleh karena itu dosen dituntut untuk memiliki kompetensi sosial yang memadai, terutama dalam kaitannya dengan Pendidikan. (Mattentuang, 2011). Masalah kompetensi dosen merupakan hal urgen yang harus dimiliki oleh setiap guru dalam jenjang pendidikan apapun. Dosen yang terampil mengajar tentu harus pula memiliki pribadi yang baik dan mampu melakukan social adjustment dalam masyarakat. Kompetensi dosen sangat penting dalam rangka penyusunan kurikulum. Ini dikarenakan kurikulum pendidikan haruslah disusun berdasarkan kompetensi yang dimiliki oleh guru. Tujuan program pendidikan, sistem penyampaian, evaluasi dan sebaginya, hendaknya direncanakan sedemikian rupa agar relevan dengan tuntutan kompetensi guru secara umum. (Mattentuang, 2011). Indikator yang diungkapkan oleh Mappanganro dalam Mattentuang (2011) mengenai kompetensi sosial, yaitu:

a.Berkomunikasi lisan, tulisan, dan isyarat

b.Menggunakan teknologi komunikasi dan informasi secara fungsional

c.Bergaul secara efektif dengan peserta didik, sesama pendidik, tenaga kependidikan, pimpinan satuan pendidikan, orang tua/wali peserta didik, bergaul secara santun dengan masyarakat sekitar dengan mengindahkan norma serta sisitem nilai yang berlaku.

d.Menerapkan prinsip-prinsip persaudaraan sejati dan semangat kebersamaan.

\section{Kompetensi Profesional}

Berbicara mengenai profesional pemikiran kita pasti akan tertuju kepada sebuah pekerjaan. Menurut Danim, Sudarmawan mengartikan profesional 
dengan mengaitkannya kepada dua hal, yaitu yang pertama adalah seseorang yang menyandang sebuah profesi atau pekerjaan. Orang yang profesional biasanya melakukan pekerjaan yang sesuai dengan keahlian yang dimilikinya dan mengabdikan diri pada pengguna jasa dan bertanggung jawab atas pekerjannya tersebut. Kedua, kata profesional dapat dikaitkan dengan kinerja atau performance seseorang dalam melakukan pekerjaan yang sesuai dengan profesinya ( Romli, 2016). Sedangkan kompetensi profesional merupakan orang yang di pandang ahli dalam bidangnya dan penguasaan materi secara luas sehingga dapat di nyatakan sebagia dosen yang profesional dan memungkinkan membimbing peserta didik memenuhi kewajiban nya dan memenuhi standar kompetensi yang di terapkan dalam standar nasional pendidikan. dengan memiliki kompetensi yang memadai maka seseorang dapat melakukan pekerjaan dan menghasilkan kinerja yang baik . (fathorrahman, 2017). Menurut Anwar profesional dapat diartikan sebagai sebuah komitmen seseorang yang memilii sebuah profesi untuk meningkatkan kemampuan profesionalnya dengan secara terusmenerus mengembangkan strategistrategi yang digunakannya dalam melakukan pekerjaan sesuai dengan profesinya.. Kompetetensi profesional merupakan penguasaan materi pembelajaran secara luas dan mendalam yang mencangkup penguasaan materi kurikulum mata pembelajaran di kampus dan substansi keilmuan yang menaugi materinya, serta penguasaan terhadap struktur dan metodologi keilmuannya. (Yahya dan Hidayati, 2014)

Dari pendapat diatas jelaslah bahwa seorang yang dikatakan profesional adalah orang yang dipandang ahli dalam bidangnya, di mana yang bersangkutan bisa membuat keputusan dengan independen dan adil. Jika seorang menjadi profesional, haruslah membuat suatu langkah penawaran kolektif dengan membangun proses yang baru, institusi yang baru, prosedur yang baru, yang menggiring pada suatu pemahaman yang diinginkan pendidik: status, dignitas, profesional, dan kompensasi yang logis dari suatu pekerjaan profesional (Romli, 2016).

Secara ringkas indikator kompetensi profesional guru/dosen dapat digambarkan sebagai berikut:

a. Memiliki keterampilan mengajar yang baik.

b. Memiliki wawasan yang luas.

c. Menguasai kurikulum.

d. Menguasai media pembelajaran.

e. Penguasaan teknologi.

f. Memiliki kepribadian yang baik. g. Menjadi teladan yang baik.

\section{Penilaian Kinerja}

Penilaian kinerja (performance appraisal) adalah mengevaluasi kinerja karyawan dimasa sekarang dan/atau dimasa lalu secara relatif terhadap standar kinerjanya. Penilaian kinerja juga membutuhkan penetapan standar kinerja dan berasumsi bahwa karyawan menerima pelatihan, umpan balik, dan insentif yang dibutuhkan untuk menghasilkan defisiensi kinerj. Pada intinya penilaian kinerja selalu melibatkan proses penilaian kinerja (performance appraisal process) meliputi tiga langkah: (1). Menetapkan standar kerja (2). Menilai kinerja aktual karyawan secara relatif terhadap standar (3). Memberikan umpan balik kepada karyawan dengan tujuan membantunya untuk menghasilkan definisi kinerja atau kinerja di atas standar. ( Gary Dessler, 2016)

Mangkunegara mengatakan bahwa penilaian kinerja karyawan pada dasar nya merupakan penilaian yang sistematik terhadap penampilan kerja karyawan itu sendiri dan terhadap paraf potensi karyawan dalam upaya 
mengembangkan diri. Manfaat penilaian kinerja bagi perusahan adalah sebagai alat dalam pengambilan keputusan oleh pemimpin bermanfaat bagi karyawan untuk mengetahui kekurangan, potensi, tujuan, rencana dan pengembangan karir karyawan. pelayanan pendidikan sesuai dengan kebutuhan seluruh pemangku kepentingan. Indikator penilaian kinerja :

a. Penetapan penilaian kerja

b. Penetapan standar kerja

c. Pelaksana pengukuran prestasi kerja

d. Pengadaan umpan balik

\section{Kerangka Pemikiran}

Untuk lebih memperjelas arah dari penelitian yang menunjukkan bahwa ada pengaruh antara kompetensi sosial dan kompetensi profesional terhadap penilaian kinerja dosen maka dalam penelitian ini dapat diambil satu jalur pemikiran yang diterjemahkan dalam diagram struktur.Berdasarkan kerangka pemikiran diatas maka dapat dibuat kerangka konseptual seperti pada gambar dibawah ini:

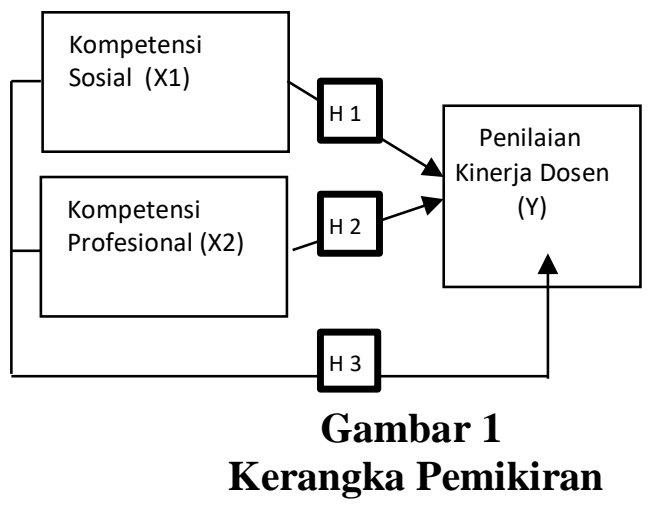

Kerangka pikir penelitian di atas merupakan runtutan pola dalam melakukan penelitian terkait pengaruh kompetensi sosial dan kompetensi profesional terhadap penilaian kinerja dosen Fakultas Ekonomi dan Bisnis Universitas Dharma Andalas Padang. Variabel terikat dalam penilitian adalah penilaian kinerja (Y) sedangkan variabel bebas meliputi kompetensi sosial (X1) dan kompetensi profesional (X2).

Pengembangan Hipotesis
Hipotesis merupakan dugaan sementara atas suatu hubungan, sebab akibat dari kinerja variabel yang perlu dibuktikan kebenarannya, dari uraian diatas dapat ditarik hipotesis atau dugaan sementara. Berdasarkan hal-hal yang dikemukakan diatas maka dapat dirumuskan hipotesissebagai berikut:

H1: Diduga terdapat pengaruh signifikan kompetensi sosial terhadap penilaian kinerja Dosen Universitas Dharma Andalas Padang.

H2: Diduga terdapat pengaruh signifikan kompetensi profesional terhadap penilaian kinerja Dosen Universitas Dharma Andalas Padang.

H3: Diduga terdapat pengaruh signifikan kompetensi sosial dan kompetensi profesional secara simultan terhadap penilaian kinerja Dosen Universitas Dharma Andalas Padang.

\section{METODE PENELITIAN}

Penelitian ini merupakan penelitian kuantitatif dan deskriptif yaitu menjelaskan pengaruh penilaian kinerja dosen terhadap kompetensi sosial dan kompetensi propesional. Dilihat dari sudut pandang kompetensi sosial dan kompetensi propesional dalam mempertimbangkan penilaian kinerja dosen Universitas Dharma Andalas. Pendekatan penelitian ini adalah penelitian survey. penelitian survey merupakan suatu penelitian kuantitatif dengan menggunakan pertanyaan terstruktur atau sistematika yang sama kepada banyak orang, untuk kemudian seluruh jawaban yang diperoleh oleh peneliti, di catat, diolah dan di analisa.. Dalam penelitian ini, penulis menggunakan metode penelitian yang bersifat kuantitatif. Menurut Sugiyono (2017), penelitian kuantitatif merupakan metode penelitian yang digunakan untuk meneliti pada populasi atau sampel tertentu, pengumpulan data menggunakan instrument penelitian, 
analisis data bersifat kuantitatif atau statistik, dengan tujuan untuk menguji hipotesis yang telah ditetapkan.

Populasi dalam penelitian. ini adalah Mahasiswa Jurusan Akuntansi FEB Universitas Dharma Andalas, mulai dari bp 16, 17, dan 18, tahun ajaran 2018/2019. Hair, dkk (2006) menyatakan, ukuran sampel sebaiknya jumlah indikator pada variabel dikalikan 5-10. Pada penelitian ini terdapat 25 item pertanyaan, dengan demikian sampel dalam penelitian berkisar antara 140-280 responden, sampel yang diambil sebanyak 210 responden. Metode pengambilan sampel secara random sampling. Random sampling adalah sesuatu cara pengambilan sampel yang memberkan kesempatan atau peluang yang sama untuk diambil kepada setiap elemen populasi.

Sampel adalah bagian tertentu dari unit populasi. Menurut Sugiyono (2014) sampel adalah bagian dari jumlah dan karakteristik yang dimiliki pada populasi. Pada sampel ini yang diambil yaitu bagian mahasiswa mulai dari $\mathrm{BP}$ 16, 17, dan 18. Maka peneliti menggunakan random sampling dalam penelitian ini sampel yang dapat yaitu 210 orang mahasiswa dari jumlah seluruh populasi mahasiswa Fakultas Ekonomi dan Bisnis (FEB) Prodi S1 dan D3 Akuntansi. Sampel adalah bagian dari jumlah dan karakteristik yang dimiliki oleh populasi tersebut. Untuk mendapatkan penelitian ini dilakukan dengan cara random sampling terhadap penilaian kinerja dosen fakultas Ekonomi dan Bisnis (FEB) Universitas Dharma Andalas Padang .Random sampling adalah teknik pengambilan sampel dari anggota populasi yang di lakukan secara acak tampa memperhatikan rata- rata yang ada dalam populasi itu. Penelitian memakai cara ini karena paling mudah dan cepat di lakukan. Jadi sampel yang diambil dalam penelitian ini adalah 210 mahasiswa fakultas Ekonomi dan Bisnis (FEB) prodi S1 dan D3 Akuntansi.

Metode analisis data meliputi uji validitas dan reliabilitas, kemudian uji asumsi klasik yang terdiri dari uji normalitas, Uji Multikolinearitas, Uji Heteroskedastisitas serta metode analisa data yang dipergunakan adalah analisis Regresi Berganda, sementara untuk uji hipotesis terdiri dari Uji Parsial (Uji t) serta Uji Signifikasi Simultan (Uji F) dan juga melihat hasil uji Koefisien Determinasi $\left(\mathrm{R}^{2}\right)$.

\section{HASIL DAN PEMBAHASAN}

Berdasarkan hasil pentabulasian data dapat disimpulkan dari 210 responden, paling banyak didominasi oleh perempuan yaitu sebanyak 138 orang (66\%), sedangkan responden lakilaki berjumlah 72 orang (34\%). Sementara dari usia responden yang banyak ditemui dalam penelitian ini adalah yang berusia 19 tahun yaitu sebanyak 84 orang (40\%), kemudian pada umumya responden yang aktif pada semester 2 yaitu sebanyak 110 orang (52\%), dengan jurusan terbanyak berasal dari program studi D3 Akuntansi yaitu sebanyak 110 orang $(52 \%)$ dari keseluruhan responden.

\section{Analisis Data}

Uji validitas dilakukan untuk mengetahui apakah alat ukur yang telah di susun dapat di gunakan untuk mengukur apa yang hendak di ukur secara tepat. Korelasi antara masingmasing indikator terhadap total skor dari setiap variabel menunjukkan hasil yang signifikan, dan menunjukkan bahwa Total Item Corelation > cut off dimana $\mathrm{r}$ tabel bernilai 0.30. Dengan demikian indikator atau kuesioner yang digunakan oleh masing-masing variabel kompetensi sosial, kompetensi profesional dan penilaian kinerja dosen dinyatakan valid untuk digunakan sebagai alat ukur variabel.

Uji Reliabilitas 
Reliabilitas alat ukur adalah kesesuaian alat ukur dengan yang diukur, sehingga alat ukur dapat di percaya atau dapat di handalkan (Bungin 2005). Hasil uji reliabilitas menunjukkan bahwa semua variabel mempunyai koefisien Alpha yang cukup besar yaitu diatas 0,60 sehingga dapat dikatakan semua konsep pengukur masing-masing variabel dari kuesioner adalah reliabel

\section{Uji Normalitas}

dilakukan dengan menggunakan

kolmogrov-Smirnov (KS) dengan kriteria pengujian $\alpha=0.05$ Dalam penelitian ini, uji normalitas adalah sebagai berikut:

\section{Tabel 1}

Hasil Uji Normalitas

One-Sample Kolmogorov-Smirnov Test

\begin{tabular}{|c|c|c|}
\hline & & $\begin{array}{l}\text { Unstandardized } \\
\text { Residual }\end{array}$ \\
\hline $\mathrm{N}$ & & 210 \\
\hline \multirow[t]{2}{*}{ Normal Parameters ${ }^{a}$} & Mean & .0000000 \\
\hline & Std. Deviation & 3.90666151 \\
\hline \multirow[t]{3}{*}{ Most Extreme Differences } & Absolute & .035 \\
\hline & Positive & .031 \\
\hline & Negative & -.035 \\
\hline Kolmogorov-Smirnov Z & & .514 \\
\hline Asymp. Sig. (2-tailed) & & .954 \\
\hline
\end{tabular}

Sumber : Olahan SPSS, 2019

Berdasarkan uji normalitas dengan menggunakan uji sample kolmogrov-smirnov test, terlihat bahwa nilai absolute untuk variabel residual sebesar 0,035 dan Asymp. Sig pada 0,954 $>0,05$ hal ini mengindikasi bahwa data residual terdistribusi normal.

\section{Uji Multikoliniaritas}

Uji ini bertujuan untuk menguji apakah model regresi ditemukan adanya korelasi antar variabel bebas (independen). Menurut Ghozali (2013) Model regresi yang baik seharusnya tidak terjadi korelasi di antara variabel independen. Jika variabel independen saling berkorelasi, maka variabelvariabel ini tidak ortogonal Ghozali (2013). Menurut Wijaya (2014) Untuk mendeteksi adanya multikolinearitas, dapat dilihat dari Value Inflation Factor (VIF). Apabila nilai VIF > 10, terjadi multikolinieritas. Sebaliknya, jika VIF < 10, tidak terjadi multikolinearitas.

Untuk analisisnya dengan SPSS kita lihat hasil output pada tabel "Coefficients" seperti pada Tabel 2 berikut ini:

Tabel 2

Uji Multikoloniaritas

Coefficients $^{\mathrm{a}}$

\begin{tabular}{llll}
\hline \multicolumn{4}{c}{ Coefficients $^{\mathrm{a}}$} \\
\multicolumn{2}{l}{ Model } & \multicolumn{2}{l}{ Collinearity Statistics } \\
& (Colerance & VIF \\
\hline 1 & (Constant) & & \\
& Kompetensi Sosial & .590 & 1.694 \\
& Kompetensi Profesional & .590 & 1.694 \\
\hline
\end{tabular}

Sumber : Olahan SPSS, 2019

Dari hasil output data didapatkan bahwa semua nilai VIF < 10 ini berarti tidak terjadi multikolonieritas. Dan menyimpulkan bahwa uji asumsi klasik terpenuhi.

\section{Uji Heteroskedastisitas}

Uji heteroskedastisitas adalah untuk melihat apakah terdapat ketidaksamaan varians dari residual satu ke pengamatan yang lain. Model regresi yang memenuhi persyaratan adalah dimana terdapat kesamaan varians dari residual satu pengamatan ke pengamatan yang lain tetap atau disebut homoskedastisitas (Kurniawan, 2014). untuk menganalisis datanya kita lihat pada gambar "Scatterplot" pada output data. seperti pada gambar 2 berikut ini :

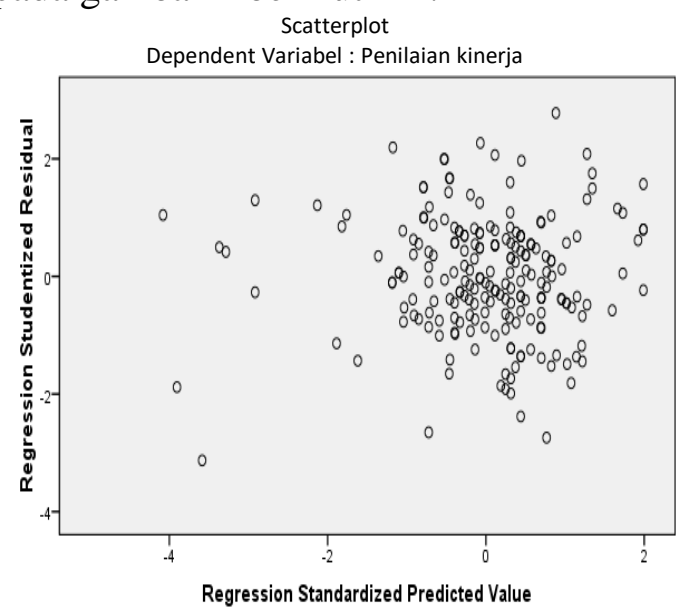

Gambar 2

Uji Heteroskedastisitas (Scatterplot) 
Dari gambar 2 dapat diketahui tidak terjadi heteroskedastisitas sebab ada pola yang tidak jelas serta titik-titik menyebar di atas dan di bawah angka 0 pada sumbu Y, sehingga dapat dikatakan uji asumsi klasik terpenuhi.

\section{Analisis Regresi Linier Berganda}

Dalam penelitian ini, analisis regresi linier berganda adalah sebagai berikut :

\section{Tabel 3}

Analisis Regresi Linier Berganda dan Uji Parsial (t)

\begin{tabular}{|c|c|c|c|c|c|}
\hline \multirow{2}{*}{ Model } & \multicolumn{2}{|c|}{$\begin{array}{l}\text { Unstandardized } \\
\text { Coefficients }\end{array}$} & $\begin{array}{l}\text { Standardized } \\
\text { Coefficients }\end{array}$ & \multirow{2}{*}{$\mathrm{T}$} & \multirow{2}{*}{ Sig. } \\
\hline & B & $\begin{array}{l}\text { Std. } \\
\text { Error }\end{array}$ & Beta & & \\
\hline 1 (Constant) & 14.010 & 2.195 & & 6.384 & .000 \\
\hline $\begin{array}{l}\text { Kompetensi } \\
\text { Sosial }\end{array}$ & .285 & .127 & .137 & 2.242 & .026 \\
\hline $\begin{array}{l}\text { Kompetensi } \\
\text { Profesional }\end{array}$ & .820 & .078 & .641 & 10.483 & .000 \\
\hline
\end{tabular}

Dependent Variabel Penilaian Kinerja

Sumber Data : Olahan SPSS 2019

Berdasarkan tabel 3 dapat

diketahui persamaan regresi yang terbentuk adalah:

$\mathrm{Y}=\mathrm{a}+\mathrm{b} 1 \mathrm{X} 1+\mathrm{b} 2 \mathrm{X} 2+\mathrm{e}$

$\mathrm{Y}=14,010+0,285 \mathrm{X} 1+0,820 \mathrm{X} 2+\mathrm{e}$

Dari persamaan tersebut dapat dijelaskan bahwa:

1. Dari persamaan regresi berganda diatas terlihat bahwa nilai konstanta sebesar 14,010 menunjukan bahwa tanpa adapun variabel bebas yaitu Kompetensi Sosial dan Kompetensi Profesional maka Penilaian Kinerja Dosen bernilai positif sebesar 14,010.

2. Nilai koefisien Kompetensi Sosial (X1) yakni 0,285 dan nilai signifikansinya 0,285 Kompetensi Sosial kerja fisik meningkat sebesar satu-satuan maka Penilaian Kinerja Dosen (Y) akan meningkat sebesar 0,285 .

3. Nilai koefisien Kompetensi Profesional (X2) yakni 0,820. Hal ini menunjukan bahwa apabila Kompetensi Profesional meningkat sebesar satu-satuan maka Penilaian
Kinerja Dosen (Y) akan meningkat sebesar 0,820.

\section{Uji Hipotesis}

Dalam penelitian ini, hasil uji parsial (uji t) dapat dilihat pada tabel 3. Berdasarkan tabel diatas menunjukkan bahwa uji hipotesis secara parsial adalah sebagai berikut :

1. Hasil pengujian hipotesis kompetensi sosial menunjukkan nilai $\mathrm{t}$ hitung sebesar 2.242 dengan taraf signifikansi 0.026 . Taraf signifikansi tersebut lebih kecil dari 0.05 , yang berarti bahwa hipotesis dalam penelitian ini menolak Ho dan menerima Ha. Dengan demikian dapat berarti bahwa hipotesis $\mathrm{H} 1$ adalah kompetensi sosial mempunyai pengaruh signifikan terhadap penilaian kinerja dosen Fakultas Ekonomi dan Bisnis Universitas Dharma Andalas.

2. Hasil pengujian hipotesis kompetensi profesional menunjukkan nilai $t$ hitung sebesar 10.483 dengan taraf signifikansi 0.000. Taraf signifikansi tersebut lebih kecil dari 0.05 , yang berarti bahwa hipotesis dalam penelitian ini menolak Ho dan menerima Ha. Dengan demikian dapat berarti bahwa hipotesis $\mathrm{H} 2$ adalah kompetensi profesional mempunyai pengaruh signifikan terhadap penilaian kinerja dosen Fakultas Ekonomi dan Bisnis Universitas Dharma Andalas.

Hipotesis dalam penelitian ini diuji kebenarannya dengan menggunakan uji simultan. Pengujian dilakukan dengan melihat taraf signifikansi, jika taraf signifikansi yang dihasilkan dari perhitungan di bawah 0,05 maka hipotesis diterima, sebaliknya jika taraf signifikansi hasil hitung lebih besar dari 0,05 maka

hipotesis ditolak. Dalam penelitian ini uji F dari Kompetensi Sosial dan Kompetensi Profesional sebagai berikut : 
Tabel 4

Hasil Uji Simultan

\begin{tabular}{|c|c|c|c|c|c|c|}
\hline \multicolumn{7}{|c|}{ ANOVA $^{b}$} \\
\hline \multicolumn{2}{|c|}{ Model } & \multirow{2}{*}{$\begin{array}{r}\begin{array}{l}\text { Sum of } \\
\text { Squares }\end{array} \\
3786.17\end{array}$} & \multirow{2}{*}{$\frac{\mathrm{Df}}{2}$} & \multirow{2}{*}{$\begin{array}{c}\begin{array}{c}\text { Mean } \\
\text { Square }\end{array} \\
1893.08\end{array}$} & \multirow{2}{*}{$\frac{F}{122.85}$} & \multirow{2}{*}{$\frac{\text { Sig. }}{.000^{\mathrm{a}}}$} \\
\hline 1 & Regression & & & & & \\
\hline & Residual & 3189.76 & 207 & 15.409 & & \\
\hline & Total & 6975.92 & 209 & & & \\
\hline
\end{tabular}

Sumber Data : Olahan SPSS 2019

Dari tabel 4 terlihat bahwa Hasil pengujian hipotesis kompetensi sosial dan kompetensi profesional menunjukkan nilai $\mathrm{F}$ hitung sebesar 122,85 dengan taraf signifikansi 0,000 . Taraf signifikansi tersebut lebih kecil dari 0,05 , yang berarti bahwa hipotesis dalam penelitian ini menolak Ho dan menerima Ha. Dengan demikian dapat berarti bahwa hipotesis $\mathrm{H} 3$ adalah kompetensi sosial dan kompetensi profesional mempunyai pengaruh signifikan terhadap penilaian kinerja dosen Fakultas Ekonomi dan Bisnis Universitas Dharma Andalas.

\section{Analisa Koefisien Determinasi $\left(\mathbf{R}^{\mathbf{2}}\right)$}

Pada dasarnya uji ini mengukur sejauh mana kemampuan model dalam menerangkan variasi variabel dependen. Nilai koefisien determinasi adalah antara nol dan satu (Ghozali, 2009). Nugroho (2005), menyatakan untuk regresi linear berganda sebaiknya menggunakan $R$ square yang sudah disesuaikan atau tertulis Adjusted $R$ square untuk melihat koefisien determinasi, karena disesuaikan dengan jumlah variabel independen yang digunakan, dimana jika variabel independen 1 (satu) maka menggunakan $R$ square dan jika telah melebihi 1 (satu) menggunakan adjusted $R$ square. Hasil uji koefisien determinasi dalam penelitian ini adalah sebagai berikut :

Tabel 5

Analisis Koefisien Determinasi Model Summary ${ }^{b}$

\begin{tabular}{rrrrr}
\hline Model & R & R Square & $\begin{array}{l}\text { Adjusted } \\
\text { R Square }\end{array}$ & $\begin{array}{l}\text { Std. Error of } \\
\text { the Estimate }\end{array}$ \\
\hline 1 & $.737^{a}$ & .543 & .538 & 3.925 \\
\hline
\end{tabular}

Sumber Data : Olahan SPSS 2017
Berdasarkan

tabel 5 menunjukkan besar pengaruhnya Kompetensi Sosial dan Kompetensi Profesional mempunyai pengaruh terhadap Penilaian Kinerja Dosen adalah sebesar 0,538 atau $53,8 \%$ sedangkan sisanya $46,2 \%$ dipengaruhi oleh faktor lainnya

\section{Pengaruh Kompetensi Sosial Terhadap Penilaian Kinerja Secara Parsial}

Hasil pengujian hipotesis Kompetensi Sosial menunjukkan nilai $\mathrm{t}$ hitung sebesar 2,242 dengan nilai signifikansi 0,026 . Nilai signifikansi tersebut lebih kecil dari 0,05 , yang berarti bahwa hipotesis dalam penelitian ini menolak Ho dan menerima $\mathrm{Ha}$. Dengan demikian dapat berarti hipotesis H1 bahwa Kompetensi Sosial berpengaruh positif dan signifikan terhadap Penilaian Kinerja Dosen Universitas Dharma Andalas. Hal ini berarti semakin meningkatnya Kompetensi Sosial Dosen Universitas Dharma Andalas maka penilaian kinerja semakin meningkat seperti: Kemampuan menyampaikan pendapat, kemampuan menerima kritikan, mengenal dengan baik mahasiswa yang mengikuti kuliahnya, mudah bergaul di kalangan sejawat, karyawan dan mahasiswa dan terakhir toleransi terhadap keberagaman mahasiswa.

Hasil penelitian ini sejalan dengan penelitian terdahulu oleh Irianto (2015) yang penelitiannya berjudul "Pengaruh Kompetensi Pedagogik, Profesional, Kepribadian dan Sosial yang Dimiliki Dosen Terhadap Hasil Belajar Mahasiswa". Dimana hasil penelitiannya adalah kompetensi sosial berpengaruh signifikan terhadap penilaian kinerja dosen. Namun penelitian ini tidak sejalan dengan Fathorrahman (2017) yang penelitiannya berjudul "Kompetensi Pedagogik, Profesional, Kepribadian dan Kompetensi Sosial Dosen". Dimana hasil penelitiannya 
adalah kompetensi sosial tidak berpengaruh signifikan terhadap kinerja dosen.

\section{Pengaruh Kompetensi Profesional Terhadap Penilaian Kinerja Secara Parsial}

Hasil pengujian hipotesis Kompetensi Profesional menunjukkan nilai $\mathrm{t}$ hitung 10,483 dengan nilai signifikansi 0,000 . Nilai signifikansi tersebut lebih kecil dari 0,05 , yang berarti bahwa hipotesis dalam penelitian ini menolak Ho dan menerima Ha. Dengan demikian dapat berarti hipotesis H2 bahwa "Kompetensi Profesional berpengaruh positif dan signifikan terhadap Penilaian Kinerja Dosen Universitas Dharma Andalas". Hal ini berarti semakin meningkatnya Kompetensi Profesional Dosen Universitas Dharma Andalas maka penilaian kinerja semakin meningkat seperti: Kemampuan menjelaskan pokok bahasa/topik secara jelas, kemampuan menjelaskan keterkaitan bidang/topik yang di ajarkan dengan bidang/topik lain nya, kemampuan memberikan contoh relevan dari konsep yang di ajarkan, kemampuan menjelaskan keterkaitan bidang/topik yang di ajarkan dengan konteks kehidupan, penguasaan akan isu-isu mutakhir dalam bidang yang di ajarkan, penggunaan hasil-hasil penelitia dosen untuk meningkatkan kualitas perkuliahan, melibatkan mahasiswa dalam penelitian/kajian atau pengembangan/rekayasa/desain serta Kemampuan menggunakan beragam teknologi komunikasi.

Hasil penelitian ini sejalan dengan penelitian Fathorrahman (2017) yang penelitiannya berjudul "Kompetensi pedagogik, profesional, kepribadian dan kompetensi sosial dosen". Dimana hasil penelitiannya adalah kompetensi profesional berpengaruh positif terhadap kinerja dosen. Dan penelitian ini juga sejalan dengan penelitian Yahya (2014) yang penelitiannya berjudul "Analisis Kompetensi terhadap Penilaian Kinerja (Studi Kasus Dosen UIN Sultan Syarif Kasim Riau)". Hasil penelitiannya adalah Kompetensi Profesional berpengaruh signifikan terhadap penilaian kinerja dosen UIN Sultan Syarif Kasim Riau.

\section{Pengaruh Kompetensi Sosial dan Kompetensi Profesional terhadap Penilaian Kinerja Dosen}

Hasil pengujian hipotesis Lingkungan kerja fisik, dan Lingkungan kerja non fisik menunjukkan nilai $\mathrm{F}$ hitung 122,852 dengan nilai signifikansi 0,000. Nilai signifikansi tersebut lebih kecil dari 0,05, yang berarti bahwa hipotesis dalam penelitian ini menolak Ho dan menerima Ha. Dengan demikian dapat berarti hipotesis $\mathrm{H} 3$ bahwa Kompetensi Sosial dan Kompetensi Profesional mempunyai pengaruh positif dan signifikan terhadap Penilaian Kinerja Dosen Universitas Dharma Andalas.

Hasil penelitian ini sejalan dengan penelitian terdahulu oleh Yahya (2014) yang penelitiannya berjudul "Analisis Kompetensi Terhadap Penilaian Kinerja (Studi Khasus Dosen Uin Sultan Syarif Kasim Riau)". Dimana hasil penelitiannya adalah Pengaruh kompetensi pedagogik, kompetensi profesional, kompetensi ke pribadian dan kompetensi sosial, secara simultan (bersama-sama) berpengaruh signifikan. Selain itu hasil penelitian ini sejalan dengan penelitian yang dilakukan oleh Fathorrahman (2017) yang penelitiannya berjudul "Kompetensi Pedagogik, Profesional, Kepribadian dan Kompetensi Sosial Dosen". Dimana hasil penelitiannya adalah Kompetensi Pedagogik, Profesional, Kepribadian dan Kompetensi Sosial Dosen berpengaruh signifikan terhadap kinerja dosen.

\section{SIMPULAN}

Berdasarkan hasil analisis 
tentang pengaruh kompetensi pedagogik dan kompetensi kepribadian terhadap penilaian kinerja dosen, maka dapat diambil kesimpulan sebagai berikut :

1. Hasil pengujian hipotesis Kompetensi Sosial menunjukkan nilai $\mathrm{t}$ hitung sebesar 2,242 dengan nilai signifikansi 0,026 . Nilai signifikansi tersebut lebih kecil dari 0,05, yang berarti bahwa hipotesis dalam penelitian ini menolak Ho dan menerima Ha. Dengan demikian dapat berarti hipotesis $\mathrm{H} 1$ bahwa Kompetensi Sosial berpengaruh positif dan signifikan terhadap Penilaian Kinerja Dosen Universitas Dharma Andalas. Hal ini berarti semakin meningkatnya Kompetensi Sosial Dosen Universitas Dharma Andalas maka penilaian kinerja semakin meningkat

2. Hasil pengujian hipotesis Kompetensi Profesional menunjukkan nilai $t$ hitung 10,483 dengan nilai signifikansi 0,000 . Nilai signifikansi tersebut lebih kecil dari 0,05 , yang berarti bahwa hipotesis dalam penelitian ini menolak Ho dan menerima Ha. Dengan demikian dapat berarti hipotesis $\mathrm{H} 2$ bahwa Kompetensi Profesional berpengaruh positif dan signifikan terhadap Penilaian Kinerja Dosen Universitas Dharma Andalas. Hal ini berarti semakin meningkatnya Kompetensi Profesional Dosen Universitas Dharma Andalas maka penilaian kinerja semakin meningkat

3. Hasil pengujian hipotesis Kompetensi Sosial dan Kompetensi Profesional menunjukkan nilai $\mathrm{F}$ hitung 122.852 dengan nilai signifikansi 0,000 . Nilai signifikansi tersebut lebih kecil dari 0,05 , yang berarti bahwa hipotesis dalam penelitian ini menolak Ho dan menerima Ha. Dengan demikian dapat berarti hipotesis H3 bahwa Kompetensi Sosial dan Kompetensi Profesional mempunyai pengaruh positif dan signifikan terhadap
Penilaian Kinerja Dosen Universitas Dharma Andalas. Besar pengaruhnya Kompetensi Sosial dan Kompetensi Profesional mempunyai pengaruh terhadap Penilaian Kinerja Dosen adalah sebesar 0,538 atau $53,8 \%$ sedangkan sisanya $46,2 \%$ dipengaruhi oleh faktor lainnya.

4. Variable yang memiliki pernguruh terbesar terhadap penilaian kineja dosen adalah kompetensi profesional dosen, seperti kemampuan dalam menjelaskan pokok/topik secara jelas, kemampuan memberikan contoh relevan dari konsep yang diajarkan, kemampuan menggunakan beragam teknologi komunikasi, serta penggunaan hasil-hasil penelitian dosen untuk meningkatkan kualitas perkuliahan

Usulan perbaikan untuk meningkatkan Kinerja Dosen FEB Universitas Dharma Andalas adalah sebagai berikut :

a. Untuk melakukan penilaian kinerja dosen di FEB Unidha perlu dperhatikan hal yang sangat mendasar, Dengan cara jelas penyampaian tujuan dan manfaat perkuliahan, memulai dan menghakiri perkulihan tepat waktu dan sesuai jadwal, dosen memberikan kesempatan bertanya,menanggapi pertanyaan/ komentar dan adanya penggunaan buku acuan dan literatur yang muthakir(>5 tahun).Menambah objek penilaian lain seperti dinilai oleh rekan kerja, dan atasan (pimpinan), sehingga penilaiannya dapat menyeluruh di semua bagian struktru organisasi.

b. Untuk pihak Universitas perlu mendukung aktivitas dosen berupa kegiatan-kegiatan pelatihan, seminar dalam upaya peningkatan kinerja dosen kedepannya. 
DAFTAR PUSTAKA

Bungin, B. 2005. Metode Penelitian Kuatuitatif. Jakarta: Penerbit Prenada Media.

Dessler, G. 2015.Manajemen Sumber Daya Manusia. Jakarta: Penerbit Salemba Empat.

Fathorrahman. 2017. "Kompetensi Pedagogik, Profesional, Kepribadian dan Kompetensi Sosial Dosen". Jurnal Akademika; Vol 15 No 1 Februari 2017. Sekolah Tinggi Ilmu Ekonomi ASIA Malang.

Ghozali, Imam. 2009. Ekonometrika Teori, Konsep dan Aplikasi dengan Program SPSS 17. Semarang Badan Penerbit Universitas Diponegoro.

Hair, J. F, Black, W. C, Babin, B.J, Anderson, R. E., \& Tatham, R. L. 2006, "Multivariate data Analysis", Sixth Edition, New Jersey: Prentice Hall.

Irianto. 2015. Pengaruh kompetensi pedagogik, profesional, kepribadian dan sosial yang dimiliki dosen terhadap hasil belajar mahasiswa STIE AMM Malang. Jurnal bisnis dan kewirausahaan, Vol 11 No. 1 Maret 2015. STIE AMM Mataram

Kuncoro, mudrajad 2013. Metode riset untuk bisnis dan ekonomi. Jakarta: Erlangga

Kurniawan, Albert. 20014. Metode Riset untuk Ekonomi dan Bisnis : Teori Konsep, Dan praktik Penelitian Bisnis (Dilengkapi Perhitungan Pengelolaan Data dengan IBM SPSS 22.0). Bandung: Alfabeta.

Manik Sudarmin, Nova Syafrina. 2018. "Pengaruh Kompetensi Terhadap Kinerja Dosen Sekolah Tinggi Ilmu Ekonomi Riau". Jurnal Ilmiah Ekonomi dan Bisnis. Panam, Pekanbaru. STIE Ilmu Ekonomi Riau.
Mattentuang, A. 2011. Pengaruh kompetensi sosial guru terhadap peningkatan Proses Pembelajaran ( Studi Kasus SMA Negeri 11 Makasar). Skripsi : Fakultas Takbiah Dan Keguruan UIN Alauddin Makasar.

Mangkunegara, A. P. (2013). Manajemen Sumber Daya Manusia. Bandung: Perusahaan Rosda.

Nurdianti, Raden Roro Suci, 2017. "Pengaruh Kompetensi Profesional Dan Kompetensi Pedagogik Terhadap Kinerja Guru Ekonomi SMA Negeri Di Kota Bandung". Jurnal Ilmiah Manajemen dan Bisnis, Vol. 18 No 2, 2017, 177188. Universitas Siliwangi.

Nugroho, Bhuono Agung. 2005. Strategi Jitu Memilih Metode Statistik Penelitian dengan SPSS. Yogyakarta : Andi

Romli, F, M. 2016. Pengaruh kompetensi frofesional guru terhadap kemampuan berfikir kritis siswa Sekolah Dasar( Studi Kasus Sekolah Dasar Negeri Jeruk Purut 1 Kecamatan Gempolo Kabupaten Pasuruan). Skripsi : Fakultas Tarbiyah Dan Keguruan UIN Maulana Malik Ibrahim Malang.

Rivai, Veithzal dan Deddy Mulyadi. 2013. Kepemimpinan dan Prilaku Organisasi. Jakarta: penerbit Raja Grafindo Persada.

Sudaryono, Reni Febriani, Siti Rohmah. 2019. "Pengaruh Persepsi Kompetensi Dasar Dosen Terhadap Motivasi Belajar Mahasiswa (Studi pada prodi pendidikan Akuntansi Fakultas Keguruan dan Ilmu Pendidikan Universitas Banten Jaya)". Jurnal Pendidikan, Akuntansi dan Keuangan, Vol 2 No. 1, Februari 2019. E-ISSN 2622-7037. P-ISSN 
2623-0763. Serang, Indonesia : Universitas Banten Jaya

Standar Nasional Pendidikan, Pasal 28 Ayat 3

Sugiyono. (2017). metode penelitian (pendidikan kualitatif, kuantitatif, dan R\&D). Penerbit CV. Alfabeta : Bandung

Undang-Undang guru dan dosen nomor 14 tahun 2005

Yahya, Zamharil, Fitri Hidayati. 2014 "Analisis Kompetensi Terhadap Penilaian Kinerja Dosen (Studi Kasus Dosen UIN Sultan Syarif Kasim Riau). Jurnal Penelitian Sosial Keagamaan, Vol. 17, No. 1 Januari-Juni 2014

Yulianti, P., Agus, I,. \& Hastini, L.Y. 2019. Evaluasi indikator prestasi belajar mahasiswa Universitas Dharma Andalas Padang. Menara Ilmu 13(1): 116-127. 